\title{
ULOGA CRIJEVNE MIKROBIOTE U ODRŽAVANJU ZDRAVLJA SVINJA
}

\author{
Ana Žgomba Maksimović, Mirna Mrkonjić Fuka, Z. Luković
}

\begin{abstract}
Sažetak
Stabilna crijevna mikrobiota utječe na mnogo načina na održavanje ili poboljšanje zdravlja svinja. Dosadašnja istraživanja su pokazala pozitivan utjecaj crijevne mikrobiote u iskoristivosti hranjivih tvari, poboljšanju morfoloških i fizioloških svojstava gastrointestinalnog (GI) trakta, u sprječavanju prodora patogenih vrsta, a također mikroorganizmi probavila imaju važnu imunološku ulogu. Osim korisnih i poželjnih bakterijskih vrsta, crijevna mikrobiota svinja može uključivati patogene poput Salmonella spp., Clostridia spp. i patogenih sojeva E. coli. U slučaju narušene ravnoteže prirodno prisutnih mikrobnih zajednica, ovi patogeni mogu uzrokovati bolesti svinja te posljedično gubitke u proizvodnji. U prošlosti su za osiguranje stabilne mikrobiote GI trakta preventivno korišteni antibiotici, no od kada je prepoznata štetnost takve prakse sve više se koriste probiotici, prebiotici te različiti aditivi. Za takav pristup, potrebno je poznavati sastav i brojnost mikrobnih zajednica prisutnih u GI traktu svinja kao i identificirati ključne mikroorganizme u prevenciji infekcija i održavanju zdravlja domaćina. Zbog toga je u fokusu znanstvenog interesa definirati i detaljno karakterizirati crijevnu mikrobiotu zdravih jedinki, istražiti međusobne mikrobne interakcije, kao i interakcije s domaćinom, te različite načine osiguravanja stabilne crijevne mikrobiote kako bi se održala vitalnost i zdravlje životinja.
\end{abstract}

Ključne riječi: svinje, gastrointestinalni (GI) trakt, mikrobiota, probiotici, prebiotici, aditivi

\section{Uvod}

U današnje vrijeme prepoznata je uloga crijevne mikrobiote u održavanju i poboljšanju zdravlja i vitalnosti, kako ljudi, tako i različitih vrsta životinja. U svinjogojstvu, samo zdrave svinje mogu ostvariti puni genetski potencijal i osigurati kvalitetno meso uz minimalne troškove proizvodnje. Procjenjuje se da trošak hrane predstavlja dvije trećine ukupnih troškova proizvodnje, stoga je dobra iskoristivost hranjivih tvari, koja se očituje u prirastu svinja, važan čimbenik uspješnosti proizvodnje. Osim boljeg iskorištavanja hranjivih tvari, stabilna crijevna mikrobiota može na mnoge druge načine utjecati na održavanje zdravlja svinja, poput poboljšanja morfoloških i fizioloških svojstava gastrointestinalnog (GI) trakta (Kelly i King, 2001.), služi kao barijera u prodoru patogenih vrsta te ima imunološku ulogu (Lee i Mazmanian, 2010.; Che i sur., 2014.).

Stoga su mnoga istraživanja (Lamendella i sur., 2011.; Dou i sur., 2017.) fokusirana na karakterizaciju prirodno prisutnih mikroorganizama u GI traktu zdravih svinja, s ciljem identifikacije ključnih vrsta u održavanju i poboljšanju zdravlja životinja. Ranije su takva istraživanja bila ograničena na korištenje metoda temeljenih na uzgoju mikroorganizama na hranjivim podlogama, međutim zbog činjenice da je veliki broj mikroorganizama nekultivabilan, bila su potrebna alternativna rješenja za njihovu identifikaciju i karakterizaciju. U posljednja dva desetljeća razvijene su molekularne metode koje se temelje na izolaciji DNA i sekvencioniranju visoke propusnosti (eng. high-throughput sequencing (HTS)), a omogućavaju in situ uvid u

Ana Žgomba Maksimović, mag. ing. agr., izv. prof. dr. sc. Mirna Mrkonjić Fuka, prof. dr. sc. Zoran Luković, lukovic@agr.hr, Sveučilište u Zagrebu, Agronomski fakultet, Svetošimunska cesta 25, 10000 , Zagreb, Hrvatska 
sastav i funkciju prisutnih mikrobnih zajednica (Arnold i sur., 2016.). Međutim, identifikacija ključnih vrsta u održavanju vitalnosti i zdravlja domaćina i dalje predstavlja izazov, budući da istraživanja koje se baziraju na HTS analizi često daju oprečne rezultate. Zbog toga je cilj ovog rada dati pregled dosadašnjih saznanja o mikrobioti GI trakta svinja i njenoj važnosti u osiguranju zdravlja jedinki, kao i načinima manipulacije crijevnom mikrobiotom.

\section{Uspostavljanje crijevne mikrobiote prasadi}

Mikrobna kolonizacija crijeva prasadi započinje odmah nakon prasenja, kada mikroorganizmi počinju kolonizirati crijeva. Glavni čimbenici koji utječu na kolonizaciju crijeva prasadi su imunološka reakcija, prisutnost receptora u GI traktu, dostupnost i sastav hranjiva za mikrobni rast, $\mathrm{pH}$, prisutnost kisika i oksido-redukcijski potencijal (Stewart, 1997.). U prvim danima života prasadi, izvori inicijalne kontaminacije njihovog GI sustava su krmača i tlo, međutim nakon ovog početnog razdoblja mikrobiota prasadi se mijenja i razlikuje od mikrobiote krmače te postaje specifična za svaku jedinku (Katouli i sur., 1997.). Vo i sur. (2017.) su pokazali da je rano izlaganje prasadi mikroorganizmima prisutnima u tlu pozitivno utjecalo na brže sazrijevanje njihove crijevne mikrobiote, što je popraćeno smanjenjem broja potencijalno opasnih vrsta, kao i poboljšanim rastom prasadi. Smanjena izloženost prasadi mikroorganizmima u inicijalnom periodu povezuje se s usporenim uspostavljanjem zdrave probavne morfologije, fiziologije i imunoloških funkcija (Kenny i sur., 2011.). Mikrobna kolonizacija crijeva prasadi započinje aerobnim i aerotolerantnim bakterijama, nakon čega kolonizaciju mogu nastaviti i obligatorni anaerobi, budući da u prvom tjednu života prvi kolonizatori troše kisik i stvaraju anaerobne uvjete $u$ GI traktu. U intenzivnom svinjogojstvu, prasad se rano odbija od krmače (u dobi od 21 do 28 dana) te im se mijenja način hranidbe, često prije nego se uspostavi stabilna crijevna mikrobiota i u potpunosti razvije imunološki sustav. Odbićem se smanjuje mogućnost zaraze prasadi patogenima krmače, međutim praksa ranog odbića sprječava prasad da uspostavi zaštitnu crijevnu mikrofloru konzumacijom mlijeka, čime je njihov probavni trakt pogodan za kolonizaciju neželjenim mikroorganizmima. Također, rano odbiće predstavlja stres za prasad, čime se dodatno remeti normalan sastav mikrobnih zajednica i povećava osjetljivost na različite bolesti, primjerice bakterijski uzrokovanu dijareju (Lallès i sur., 2004.), koja je najčešći uzrok uginuća prasadi. Lallès i sur. (2004.) navode da tanko crijevo i mukozna ovojnica gube 20 do $30 \%$ relativne mase tijekom prva dva dana nakon odbića, a za potpuni oporavak treba 5 do 10 dana. U razdoblju nakon odbića, enterotoksični sojevi $E$. coli najčešće uzrokuju infekcije i pojavu bolesti prasadi (Lallès i sur., 2007.). Većina istraživanja provedena tijekom razdoblja prelaska s tekuće na krutu hranu pokazala su smanjen broj laktobacila i smanjenje mikrobne raznolikosti, dok se broj Clostridium spp., Prevotella spp. i Proteobacteriaceae, uključujući patogene sojeve E. coli povećao (Gresse i sur., 2017.). Sastav dominantnih mikrobnih zajednica u GI traktu sisajuće prasadi ovisi o mnogobrojnim čimbenicima, između ostalog i o izabranoj metodologiji, dizajnu istraživanja te načinu prikupljanja uzoraka. Swords i sur. (1993.) su pružili detaljan uvid u razvoj mikrobiote GI trakta tijekom prva četiri mjeseca života prasadi analizirajući uzorke fecesa konvencionalnim mikrobiološkim metodama. Pokazali su da se kolonizacija GI trakta uspostavlja vrlo brzo te 12 sati nakon prasenja ukupan broj bakterija u kolonu iznosi $10^{9} \log$ cfu/g sadržaja kolona, a već nakon 48 sati prasad u GI traktu ima $90 \%$ anaerobnih bakterija. Laktobacili i streptokoki su prepoznati kao dominantni rodovi na kraju 
prvog tjedna života te ostaju dominantni tijekom čitavog razdoblja sisanja s brojem stanica između $10^{7}-10^{9} \mathrm{cfu} / \mathrm{g}$. Suvremena istraživanja mikrobne raznolikosti se temelje na metodama neovisnima o uzgoju, poput sekvencioniranja visoke propusnosti 16S rRNA gena. U jednom takvom istraživanju, Chen i sur. (2017) su analizom uzoraka prikupljenih rektalnim brisom pokazali da se mikrobiota sisajuće prasadi uglavnom sastojala od Fusobacterium, Lactobacillus, Bacteroides, Escherichia/Shigella i Megasphaera, dok su nakon uvođenja krute hrane prevladavali rodovi Clostridium sensu stricto, Roseburia, Paraprevotella, Clostridium XIVa i Blautia. Slično tome, Vo i sur. (2017.) su uz Bacteroides i Enterobacteriaceae također identificirali i Clostridium XIVa kao dominantne u uzorcima fecesa prikupljenima tijekom razdoblja sisanja prasadi, dok su Prevotella, Megasphaera i Blautia postale dominantne nakon postupnog uvođenja krute hrane. Kao ključni čimbenici razvoja crijevne mikrobiote svinja prepoznati su dob i uvjeti rasta, uključujući i način hranidbe, dok čimbenici poput utjecaja krmače i spola imaju učinak na početku života prasadi, ali se taj učinak smanjuje s dobi (Han i sur., 2018.)

\section{Definiranje crijevne mikrobiote odraslih svinja}

Posljednjih godina su provedena brojna istraživanja sastava i strukture crijevne mikrobiote zdravih odraslih svinja s ciljem karakterizacije prisutnih mikrobnih zajednica (Leser i sur., 2002.; Collado i Sanz, 2007.; Pajarillo i sur., 2015.; Dou i sur., 2017.) U navedenim istraživanjima zabilježeni su oprečni rezultati, budući da crijevna mikrobiota ovisi o različitim čimbenicima, poput zemlje podrijetla, načina hranidbe, uzorkovanja, dobi, pasmine, kao i o dizajnu samog istraživanja. U svrhu prepoznavanja bolesnih stanja proizašlih iz narušene crijevne ravnoteže i njohovog liječenja, potrebno je definirati normalan sastav i funkciju crijevne mikrobiote. Lamendella i sur. (2011.) su proveli prvo komparativno pirosekvencioniranje metagenoma (engl. shotgun metagenomic pyrosequencing) s ciljem karakterizacije fekalnog mikrobioma svinja. Većina identificiranih bakterija je pripadala koljenima Firmicutes i Bacteroidetes, a vrste roda Prevotella su prepoznate kao dominantne. Holman i sur. (2017.) su pružili znatan doprinos razumijevanju i definiranju crijevne mikrobiote svinja provođenjem metaanalize 20 istraživanja temeljenih na metodama sekvencioniranja visoke propusnosti 16rRNA gena. Rodovi Prevotella, Clostridium, Alloprevotella, i Ruminococcus te RC9 crijevna grupa su bili detektirani kod 99 \% svih fekalnih uzoraka. Dodatno su Clostridium, Blautia, Lactobacillus, Prevotella, Ruminococcus, Roseburia, RC9 crijevna grupa i Subdoligranulum pronađeni kod $90 \%$ svih GI uzoraka, što navodi na zaključak da su ovi mikroorganizmi trajno prisutni u crijevima svinja, odnosno predstavljaju temeljnu (engl. core) mikrobiotu svinja iz komercijalnog uzgoja. Klasifikacija navedenih bakterijskih taksonomskih jedinica prikazana je u Tablici 1. Autori ovog istraživanja također ističu razlike u brojnosti bakterija u različitim dijelovima GI trakta; vrste roda Lactobacillus su bile najbrojnije u sluznici želuca, Prevotella, Helicobacter i Campylobacter u sluznici debelog crijeva, Clostridium u sluznici završnog dijela tankog crijeva (ileuma), Alloprevotella u sluznici slijepog crijeva, Bacteroides u debelom crijevu i Treponema u uzorcima fecesa. Razlike u brojnosti određenih rodova u GI traktu se mogu pripisati fiziološkim razlikama, odnosno različitim uvjetima prisutnima u različitim dijelovima probavila. Laktobacili su bili prisutni u svim navedenim dijelovima GI trakta, stoga je vjerojatno da su se proširili iz želuca i zaostali u ostalim dijelovima probavila. 
Tablica 1. Shematski prikaz taksonomije bakterija povezanih sa temeljnom (engl. core) mikrobiotom svinja i ostalih bakterija dominantnih u GI traktu.

Table 1 Taxonomy of bacteria associated with core microbiota of pigs and other bacteria dominant in their GI (gastrointestinal) tract.

\begin{tabular}{|c|c|c|c|c|}
\hline $\begin{array}{l}\text { Koljeno } \\
(\text { Phylum })\end{array}$ & $\begin{array}{l}\text { Razred } \\
\text { (Class) }\end{array}$ & $\begin{array}{c}\text { Red } \\
(\text { Order })\end{array}$ & $\begin{array}{l}\text { Porodica } \\
\text { (Family) }\end{array}$ & $\begin{array}{c}\text { Rod } \\
\text { (Genus) }\end{array}$ \\
\hline \multirow{6}{*}{ Firmicutes } & \multirow{5}{*}{ Clostridia } & \multirow{5}{*}{ Clostridiales } & Clostridiaceae & Clostridium \\
\hline & & & \multirow{2}{*}{ Ruminococcaceae } & Ruminococcus \\
\hline & & & & Subdoligranulum \\
\hline & & & \multirow{2}{*}{ Lachnospiraceae } & Blautia \\
\hline & & & & Roseburia \\
\hline & Bacilli & Lactobacillales & Lactobacillaceae & Lactobacillus \\
\hline \multirow{2}{*}{ Proteobacteria } & \multirow{2}{*}{ Epsilonproteobacteria } & \multirow{2}{*}{ Campylobacterales } & Helicobacteraceae & Helicobacter \\
\hline & & & Campylobacteraceae & Campylobacter \\
\hline \multirow{4}{*}{ Bacteroidetes } & \multirow{4}{*}{ Bacteroidia } & \multirow{4}{*}{ Bacteroidales } & Bacteroidaceae & Bacteroides \\
\hline & & & \multirow{2}{*}{ Prevotellaceae } & Prevotella \\
\hline & & & & Alloprevotella \\
\hline & & & Rikenellaceae & $\begin{array}{c}\text { Rikenellaceae RC9 } \\
\text { crijevna grupa }\end{array}$ \\
\hline Spirochaetes & Spirochaetes & Spirochaetales & Spirochaetaceae & Treponema \\
\hline
\end{tabular}

*Izvor: Holman i sur. (2017.) Source: Holman et. al. (2017)

\section{Utjecaj crijevne mikrobiote na zdravlje svinja}

Utjecaj na strukturu i funkciju GI trakta

Poznato je da crijevna mikrobiota utječe na strukturu i funkciju GI trakta te da mikrobne zajednice prisutne u GI traktu potiču peristaltiku (Falk i sur., 1998.). Istraživanja na životinjama koje nemaju uspostavljenu mikrobiotu i koje su uzgajane u sterilnim uvjetima pružaju dobar uvid u značaj mikrobnih zajednica za formiranje strukture i funkcija GI trakta. Kod takvih životinja su, u usporedbi sa životinjama iz konvencionalnog uzgoja, primijećene promjene poput smanjenja mase, debljine i dužine crijeva, uz povećanje slijepog crijeva. Redukcija intestinalne mase se može objasniti promjenama u broju stanica vezivnog tkiva sluznice (Van Kessel i sur., 2004.), uslijed izostanka podražaja imunološkog sustava zbog neuspostavljene mikrobiote. Do povećanja slijepog crijeva može doći zbog akumulacije nerazgrađene mukoze (sluzi). Mnogi tipovi stanica i tkiva u crijevima zahtijevaju prisutnost mikrobiote za pravilan razvoj i funkcionalnost (Lee i Mazmanian, 2010.). Životinje bez uspostavljene mikrobiote, izložene samo hranidbenim antigenima, imaju nerazvijeno limfno tkivo, odnosno imaju rudimentarni imunološki sustav u usporedbi sa životinjama koje su osim hranidbenim antigenima bile izložene i bakterijskim antigenima (Kelly i King, 2001.). 


\section{Stvaranje barijere patogenim vrstama i imunološka uloga}

Neželjeni mikroorganizmi mogu dospjeti u GI trakt svinja i kolonizirati ga te uzrokovati disbalans, pri čemu mogu nastati štetni i toksični proizvodi, plinovi, dijareja, konstipacija, čirevi i trovanje, te svinje ne mogu učinkovito iskorištavati hranjive tvari. Autohtona mikrobiota sprječava kolonizaciju neželjenih bakterija kompeticijom za stanište i hranjive tvari, proizvodnjom antimikrobnih tvari poput baktriocina i metaboličkom proizvodnjom tvari koje stvaraju nepovoljan okoliš za rast drugih bakterija. Sluznica (lat. mucosa) crijeva ima ključnu ulogu u stvaranju barijere i imunološkom odgovoru, a građena je od epitela i vezivnog tkiva (lamina propia). Sloj epitelnih stanica, kao i specijaliziranih bjelančevina koje se nalaze između njih, pružaju fizičku barijeru za ulazak patogena. Interakcija sa crijevnim bakterijama utječe na obnavljanje ovih stanica (Willing i Van Kessel, 2007.). Fermentacijom onih ugljikohidrata koje životinja inače ne može probaviti (prebiotika), crijevne bakterije oslobađaju kratkolančane masne kiseline, koje služe kao izvor energije za regeneraciju intestinalnog epitela. Među njima, butirat je najpovoljniji izvor energije, koji potiče normalnu proliferaciju i diferencijaciju crijevnog epitela, te proizvodnju mucina. Mucin tj. sluz, kojeg proizvode vrčaste stanice epitela probavnog trakta, predstavlja nepropustan sloj za patogene i toksine. Povećanjem broja bakterija, kao što su laktobacili, povećava se produkcija mucina što rezultira stvaranjem bolje barijere (Che i sur., 2014.). Crijevna mikrobiota također pridonosi imunomodulaciji imunološkog sustava. To se poglavito odnosi na limfatično tkivo probavnog sustava, efektorne i regulatorne T- stanice, IgA koje proizvode B plazma stanice, makrofage i dendritičke stanice koje se nalaze u vezivnom tkivu gdje mikrobiota pomaže normalnom sazrijevanju stanica te njihovoj adekvatnoj aktivaciji ključnoj za njihovo djelovanje. Fermentacija do koje dolazi u crijevima uslijed mikrobne aktivnosti stimulira imunoglobuline ( $\operatorname{IgA}$ ) i ograničava ulazak patogenih vrsta preko stanica epitela (Che i sur., 2014.). Obzirom na stalno prisustvo antigena i ostalih tvari koje se nalaze u crijevnom sadržaju, imunološki sustav mora biti precizno reguliran da se spriječi prekomjeran imunološki odgovor prema ovim čimbenicima, a istodobno imunološki odgovor mora biti brz i učinkovit prema svim povredama barijere i napada patogena, kako bi se spriječio nastanak i širenje infekcije (Moeser i sur., 2017.). Upravo je razlikovanje poželjnih i patogenih mikroorganizama najveći izazov za imunološki sustav domaćina, budući da navedeni mikroorganizmi dijele slične molekularne obrasce koje detektira imunološki sustav (Lee i Mazmanian, 2010.). Prepoznavanje specifičnih mikroorganizama može biti obilježje specijaliziranog imunološkog sustava, koji potom prilagođava imunosni odgovor ovisno o tipu prisutnog antigena (Lee i Mazmanian, 2010.). Naročitu sposobnost diferencijacije imaju plastične $\mathrm{CD}^{+} \mathrm{T}$ stanice, zbog čega mogu detektirati signale koje u okoliš šalje mikrobiota (Lee i Mazmanian, 2010.). Smatra se da je sposobnost prepoznavanja i reagiranja imunološkog sustava na specifične mikroorganizme vođena evolucijskim silama pod utjecajem same mikrobiote, što je rezultiralo imunološkim funkcijama širim od same eliminacije patogena (Lee i Mazmanian, 2010.).

\section{Utjecaj na apsorpciju hranjivih tvari}

Probava kod svinja se uglavnom oslanja na hidrolizu hranjivih tvari iz hrane u GI traktu, koja se odvija pod utjecajem endogenih probavnih enzima. Međutim, dobroj probavi uvelike doprinosi i fermentacija koja se odvija pod utjecajem mikroorganizama. Primjerice, u debelom crijevu prisutni mikroorganizmi u značajnoj mjeri fermentiraju crijevni sadržaj. Debelo 
crijevo je karakterizirano neutralnom $\mathrm{pH}$ vrijednošću, obiluje dostupnim supstratima za rast mikroorganizama, a protok probavnog materijala se odvija sporo, zbog čega pruža dobre uvjete za razvoj različitih bakterija. Crijevna mikrobiota se ponekad čak smatra zasebnim organom, zbog ključne uloge koju ima u procesiranju hranjivih tvari i iskorištavanju dobivene energije (Fouhse i sur., 2016.). McCormack i sur. (2017.) su pokazali da razlike u sastavu crijevne mikrobiote mogu, barem djelomično, objasniti učinkovitost iskorištavanja hrane kod svinja. Primijećeno je da životinje koje imaju više laktobacila bolje iskorištavaju dobivenu hranu (Fouhse i sur., 2016.). Također, pokazalo se da sastav mikrobnih zajednica varira između svinja različite tjelesne mase, s time da su bakterije iz koljena Firmicutes predominantno detektirane kod težih svinja (Pedersen i sur., 2013.). Od posebne važnosti za probavu su mikrobni enzimi koji razgrađuju inače neprobavljivu celulozu i biljne polisaharide (Backhed i sur., 2005.). Yang i sur. (2017) su pokazali da crijevna mikrobiota može utjecati na efikasnost iskorištavanja krmiva kod svinja oslobađanjem kratkolančanih masnih kiselina uslijed fermentacije polisaharida te poboljšanim iskorištavanjem bjelančevina iz krmiva. Lamendella i sur. (2011.) su uspoređujući sekvence fekalnog mikrobioma svinja s postojećim bazama sekvenci pokušali odrediti funkcije gena. Najveći broj gena bio je povezan s metabolizmom ugljikohidrata, što je autore navelo na zaključak da su bakterije u GI traktu značajne za opskrbljivanje domaćina energijom. Brojni mikrobni geni odgovorni za razgradnju komponenti biljne stanične stijenke u debelom crijevu svinja su također utvrđeni (Looft i sur., 2014.). Bakterije svojom metaboličkom aktivnošću na razne druge načine utječu na domaćina, na primjer oslobađanjem volatilnih masnih kiselina pospješuju transport vode u debelo crijevo (Yolton i Savage, 1976.), proizvode vitamin K (Ramotar i sur., 1984.) i opskrbljuju domaćina egzogenim alkalnim fosfatazama (Yolton i Savage, 1976.). Isto tako, identificirani su mikrobni geni odgovorni za sintezu esencijalnih aminokiselina i vitamina (Delzenne i Cani, 2011.).

\section{Različiti načini manipulacije crijevne mikrobiote u svrhu očuvanja zdravlja svinja}

\section{Uporaba probiotika}

U prošlosti je profilaktička uporaba antibiotika pomagala kod balansiranja ravnoteže crijevne mikrobiote i promoviranja rasta životinja, međutim takav način uporabe antibiotika je doveo do porasta broja rezistentnih bakterija, što je postao ozbiljan problem u medicini. Osim rezidua antibiotika $\mathrm{u}$ hrani i širenja rezistentnih vijabilnih bakterija kao i gena koji kodiraju za antibiotičku rezistenciju, uporabom antibiotika se osim na neželjene utjecalo i na poželjne mikroorganizme u GI traktu. Stoga je od 2011. g. na razini Europske Unije zabranjeno profilaktičko korištenje antibiotika (Gilbert, 2012.). Zbog toga se danas istražuju mogućnosti korištenja ostalih sredstava, poput probiotika i prebiotika, cinkovog oksida, esencijalnih ulja i drugih spojeva, za uspostavljanje crijevne ravnoteže (Gresse i sur., 2017.). Probiotici su definirani kao živi mikroorganizmi, koji kada su primijenjeni u dovoljnom broju doprinose zdravlju domaćina, a mogu biti formulirani kao jedan soj te kao mješavina više sojeva ili vrsta. Neke od najčešće korištenih bakterija kao probiotika u hranjivima za životinje su bakterije mliječne kiseline koje uključuju Lactobacillus spp., Enterococcus spp., Lactococcus spp., Leuconostoc spp., Pediococcus spp. i Streptococcus spp. (Liao i Nyachoti, 2017.). Bakterije mliječne kiseline se mogu vezati na crijeva domaćina i kolonizirati ga, a sposobnost vezanja ovisi o soju (Morita i sur., 2002.). U probavnom traktu domaćina, bakterije mliječne kiseline mogu 
djelovati antagonistički prema drugim bakterijama, uključujući oportunističke patogene, na različite načine. Jedan od načina je metabolička produkcija mliječne i ostalih organskih kiselina, prilikom čega se snižava $\mathrm{pH}$ vrijednost i stvara nepogodan okoliš za rast drugih bakterija, naročito Gram negativnih bakterija osjetljivih na kiseli okoliš. Također, bakterije mliječne kiseline mogu producirati druge antimikrobne tvari poput vodikovog peroksida $(\mathrm{H} 2 \mathrm{O} 2)$ i bakteriocina (Vogel i sur., 2011.). Osim bakterija mliječne kiseline, često se koriste i sojevi Bifidobacterium spp., Bacillus spp., Propionibacterium spp., Brevibacillus spp., Clostridium butyricum, Prevotella bryantii i druge (Liao i Nyachoti, 2017.). Unatoč tome što većina probiotika sadrži bakterije, kvasci i gljive se također koriste kao probiotici i najčešće uključuju Aspergillus spp., Candida spp. i Saccharomyces spp. (Liao i Nyachoti, 2017.). Jedan od najznačajnijih uvjeta za svaku probiotičku kulturu je sposobnost preživljavanja prolaska kroz GI trakt i sposobnost njegove kolonizacije u dovoljnoj mjeri da izazove pozitivan učinak na zdravlje. To se naročito odnosi na sposobnost soja da tolerira niski pH u želucu i visoku koncentraciju žučnih soli u početnom dijelu tankog crijeva. Vrijeme primjene probiotika je također značajan čimbenik za uspješnost njegovog djelovanja, a najbolje ga je primijeniti preventivno prije proliferacije patogenih bakterija i nastanka infekcije (Lodemann, 2010.). Brojna su istraživanja pokazala pozitivan utjecaj različitih probiotičkih kultura na morfologiju i fiziologiju GI trakta, smanjenje broja neželjenih i promicanje poželjnih mikroorganizama, bolju probavljivost i apsorpciju hranjivih tvari te općenito pozitivan utjecaj na zdravlje i proizvodna svojstva svinja. Morfološke promjene crijeva uslijed primjene probiotika mogu rezultirati većom apsorpcijskom površinom i posljedično, boljom apsorpcijom. Primjenom sojeva Pediococcus acidilactici i Lactobacillus acidophilus u prehrani svinja je zabilježen pozitivan učinak na rast, crijevnu mikrobiotu i morfologiju crijeva, a također je smanjena pojavnost dijareje kod prasadi pri čemu je efikasniji bio soj porijeklom iz GI trakta svinja (P. acidilactici) od soja mliječnog porijekla (Lb. acidophilus) (Dowarah i sur., 2017.). Osim poboljšanja rasta svinja, Ross i sur. (2012.) su pokazali da se primjenom probiotika može utjecati i na kvalitativni sastav mesa u obliku poboljšanog profila masnih kiselina. Autori navedenog istraživanja su pokazali da je u mesu svinja kojima su u hranu dodani sojevi Lb. amylovorus i E. faecium došlo do povećanja udjela nezasićenih masnih kiselina, prije svega linolne kiseline (C18:2), linolenske kiseline (C18:3) te cis-9, trans-11 konjugirane linolne kiseline (CLA). Slično tome, Suo i sur. (2012.) su uz poboljšani rast svinja utvrdili poboljšanu kvalitetu svinjskog mesa zbog korištenja $L b$. plantarum kao probiotika. Meso svinja čija je prehrana suplementirana ovim sojem su imale poželjniju pH vrijednost, tvrdoću i bolja svojstva kakvoće mesa. Autori ističu da se probiotički utjecaj soja, umjesto u kolonizaciji i promjenama mikrobnih zajednica GI trakta, očituje u inhibiciji rasta oportunističkih patogena i poticanju rasta crijevnih resica. Inhibiciju rasta oportunističkih patogena je pokazalo i istraživanje Pospíšková i sur. (2013.), gdje je kod krmača kojima je u hranu dodana probiotička kultura E. faecium SF 68 pokazana redukcija brojnosti E. coli i Clostridium spp. u fecesu. Bolja probavljivost hranjivih tvari može biti rezultat povećane mikrobne enzimatske aktivnosti u crijevima, bilo da sam probiotik proizvodi enzime ili zbog inducirane promjene prisutnih mikrobnih populacija koje onda proizvode enzime. Primjerice, u tankom crijevu svinja je primijećena povećana saharazna, laktazna i amilazna, iako ne i peptidazna aktivnost, nakon korištenja probiotika koji se sastojao od mješavine sojeva Lb. plantarum, Lb. acidophilus, Lb. casei i E. faecium (Collington i sur., 1990.). Također, uporabom probiotika može se utjecati i na 
moduliranje imunoloških funkcija. Uporabom soja $L b$. fermentum I5007 poboljšana je diferencijacija T-stanica i pospješena je ekspresija citokina (signalnih molekula) u tankom crijevu (Wang i sur., 2009.). Liao i Nyachoti (2017.) su utvrdili utjecaj probiotika na reproduktivna svojstva svinja, poput poboljšanja kvalitete kolostruma, kvalitete i količine mlijeka, veličinu i vitalnost legla te masu prasadi. Iako različita istraživanja pokazuju veliki potencijal primjene probiotika u svinjogojstvu, teško je uspoređivati rezultate takvih istraživanja, koja često ne pokazuju konzistentne rezultate. Razlog tome je velika varijabilnost u čimbenicima poput genotipa svinja, probiotičkim sojevima, dozi, trajanju istraživanja, načinu uzgoja, te brojnim okolišnim čimbenicima (Kenny i sur., 2011.). U novije doba, meta analizom je potvrđeno da je primjenom probiotika u početnoj i završnoj fazi rasta svinja došlo do povećanja u prosječnom dnevnom prirastu i efikasnosti iskorištavanja krmiva (Zimmermann i sur., 2016.).

\section{Uporaba prebiotika te utjecaj aditiva na crijevnu mikrobiotu svinja}

Prebiotici su definirani kao neprobavljivi sastojci koje mikroorganizmi u crijevima metaboliziraju, čime se utječe na sastav i/ili aktivnost crijevne mikrobiote i pozitivno doprinosi zdravlju domaćina (Bindels i sur., 2015.). Neki od često korištenih prebiotika uključuju inulin, fruktooligosaharide, trans galaktooligosaharide i laktulozu (Fouhse i sur., 2016.). Smatra se kako prebotici mogu biti alternativa tradicionalnim antibiotičkim promotorima rasta jer su pokazali pozitivan utjecaj kod raznih vrsta životinja. Iako je više mehanizama predloženo kao oblik djelovanja prebiotika, modificirana crijevna mikrobiota i povećana koncentracija volatilnih masnih kiselina u probavnom traktu (Liu i sur., 2018.) uz posljedičan pad $\mathrm{pH}$ vrijednosti (Mikkelsen i Jensen, 2004.; Fouhse i sur., 2016.), su najčešće zabilježeni i prihvaćeni učinci. Dodavanjem prebiotika u hranu svinja pospješuje se njihov rast uz povećanu probavljivost hranjivih tvari, smanjena je pojavnost dijareje te poboljšana morfologija tankog crijeva (Tang i sur., 2005.; Liu i sur., 2008.; Liu i sur., 2018.). Deng i sur. (2007.) su pokazali da je korištenje polisaharida sjemena biljke Senna tora (L.) Roxb. (engl. cassiae seed) kao prebiotika utjecalo na poboljšanje mikrobiote prasadi, odnosno povećan je broj laktobacila, a smanjen broj $E$. coli u crijevima prasadi. Prebiotici se također povezuju s poboljšanjem imunološkog sustava (Fleige i sur., 2009.). Prebiotici se mogu primjenjivati u kombinaciji sa probioticima, te se $u$ tom slučaju nazivaju sinbiotici. Kao alternativa profilaktičkoj upotrebi antibiotika, hrana za životinje često se suplementira različitim aditivima. Aditivi su tvari koje, dodane u hranu u malim količinama, djeluju na metabolizam i produktivnost životinja. Promjene u hrani mogu rezultirati promijenjenim sastavom mikrobnih zajednica, i posljedično, promijenjenim mikrobnim metaboličkim procesima značajnim za razgradnju različitih supstrata. Organske kiseline imaju dugu povijest korištenja kao aditiva u hrani za životinje, gdje zbog snižavanja pH vrijednosti i antimikrobnog djelovanja imaju zaštitni učinak (Kirchgessner i Roth, 1982.). Također, snižavaju $\mathrm{pH}$ u želucu i GI traktu, čime se aktiviraju određeni enzimi i pospješuje probava. Često se kao aditiv koristi natrijev butirat (sol maslačne kiseline) koji stimulira rast odbijenih svinja, te utječe na smanjenje broja koliformnih bakterija i povećanje broja laktobacila u završnom dijelu tankog crijeva te u slijepom crijevu (Galfi i Bokori, 1990.). Osim kiselinama, prehrana svinja se često obogaćuje cinkom, koji je značajan za održavanje niza staničnih funkcija. Suplementacijom visokih doza cinka u prehrani prasadi dolazi do poboljšanja morfologije tankog crijeva na način da se poveća omjer visine crijevnih resica i dubine kripti (Li i sur., 2001.). Vahjen i sur. 
(2010.) su pokazali da je kod svinja čija je prehrana suplementirana cinkovim oksidom (ZnO), da bi se spriječila dijareja, statistički veći broj vrsta rodova Weissella, Leuconostoc, i Streptococcus, dok je broj Sarcina spp. bio manji. Dodavanje bakra u prehranu je pokazalo poticanje rasta svinja, što se povezuje s njegovim bakteriostatičkim i bakteriocidnim djelovanjem, budući da bakar može utjecati na smanjenje bakterijskih populacija u crijevima (Højberg i sur., 2005.).

\section{Zaključci}

Crijevna mikrobiota od osnovnog je značaja za uspješnu hranidbu, održavanje imuniteta, vitalnosti i zdravlja svinja. Iako danas na raspolaganju imamo vrlo učinkovite metode za identifikaciju mikroorganizama bez potrebe za njihovim uzgojem na hranjivim podlogama, još uvijek nije u potpunosti razjašnjena funkcija crijevne mikrobiote kao ni jednoznačno određen sastav mikrobnih zajednica GI trakta zdravih životinja. Kao alternativa profilaktičkoj uporabi antibiotika, razmatraju se različiti pristupi, prvenstveno korištenje probiotika, prebiotika te različitih aditiva kako bi se stimulirala korisna mikrobiota i osigurala ravnoteža u sastavu i funkciji mikrobnih zajednica u GI traktu te posljedično, osiguralo zdravlje životinja i dobri proizvodni pokazatelji.

\section{LITERATURA}

1. Arnold, J. W., Roach, J., Azcarate-Peril, M. A. (2016.): Emerging Technologies for Gut Microbiome Research. Trends in Microbiology, 24(11), 887-901.

2. Backhed, F., Ley, R. E., Sonnenburg, J. L., Peterson, D. A., Gordon, J. I. (2005.): Host-bacterial mutualism in the human intestine. Science, 307(5717), 1915-1920.

3. Bindels, L. B., Delzenne, N. M., Cani, P. D., Walter, J. (2015): Towards a more comprehensive concept for prebiotics. Nature Reviews Gastroenterology \& Hepatology, 12(5), 303-310.

4. Che, L., Chen, H., Yu, B., He, J., Zheng, P., Mao, X., ... Chen., D. (2014): Long-term intake of pea fiber affects colonic barrier function, bacterial and tran- scriptional profile in pig model. Nutrition and Cancer, 66(3), 388-399.

5. Chen, L., Xu, Y., Chen, X., Fang, C., Zhao, L., Chen, F. (2017): The maturing development of gut microbiota in commercial piglets during the weaning transition. Frontiers in Microbiology, 8(1688), 1-13.

6. Collado, M. C., Sanz, Y. (2007): Characterization of the gastrointestinal mucosa-associated microbiota of pigs and chickens using culture-based and molecular methodologies. Journal of Food Protection, 70(12), 2799-2804.

7. Collington, G., Parker, D., Armstrong, D. (1990): The influence of inclusion of either an antibiotic or a probiotic in the diet on the development of digestive enzyme activity in the pig. British Journal of Nutrition, 64(1), 59-70.

8. Delzenne, N. M., Cani, P. D. (2011): Interaction between obesity and the gut microbiota: relevance in nutrition. Annual Review of Nutrition, 31, 15-31.

9. Deng, Z. Y., Zhang, J. W., Li, J., Fan, Y. W., Cao, S. W., Huang, R. L., ... Li, T. J. (2007): Effect of polysaccharides of cassiae seeds on the intestinal microflora of piglets. Asian-Australasian Journal of Animal Sciences, 16(suppl 1), 1143-1147.

10. Dou, S., Gadonna-Widehem, P., Rome, V., Hamoudi, D., Rhazi, L., Lakhal, L., ... Abdennebi-Najar, L. (2017): Characterisation of Early-Life Fecal Microbiota in Susceptible and Healthy Pigs to Post-Weaning Diarrhoea. PloS One, 12(1), 1-20. 
11. Dowarah, R., Verma, A. K., Agarwal, N., Patel, B. H. M., Singh, P. (2017): Effect of swine based probiotic on performance, diarrhoea scores, intestinal microbiota and gut health of grower-finisher crossbred pigs. Livestock Science, 195, 74-79.

12. Falk, P. G., Hooper, L. V., Midtvedt, T., Gordon, J. I. (1998): Creating and maintaining the gastrointestinal ecosystem: what we know and need to know from gnotobiology. Microbiology and Molecular Biology Reviews, 62(4), 1157-1170.

13. Fleige, S. W., Preibinger, H. H. D., Mayer, W. P. (2009): The immunmodulatory effect of lactulose on entereococcus faecium-fed preruminant calves. Journal of Animal Science, 87(5), 1731-1738.

14. Fouhse, J. M., Zijlstra, R. T., Willing, B. P. (2016). The role of gut microbiota in the health and disease of pigs. Animal Frontiers, 6(3), 30.

15. Galfi, P., Bokori, J. (1990): Feeding trial in pigs with a diet containing sodium butyrate. Acta Veterinaria Hungarica, 38(1-2), 3-17.

16. Gilbert, N. (2012): Rules tighten on use of antibiotics on farms. Nature, 481(7380), 125-125.

17. Gresse, R., Chaucheyras-Durand, F., AlainFleury, M., Van de Wiele, T., Forano, E., Blanquet-Diot, S. (2017). Gut Microbiota Dysbiosis in Postweaning Piglets: Understanding the Keys to Health. Trends in Microbiology, 25(10), 851-873.

18. Han, G. G., Lee, J. Y., Jin, G. D., Park, J., Choi, Y. H., Kang, S. K., ... Choi, Y. J. (2018): Tracing of the fecal microbiota of commercial pigs at five growth stages from birth to shipment. Scientific Reports, 8(6012), $1-9$.

19. Højberg, O., Canibe, N., Poulsen, H. D., Hedemann, M. S., Jensen, B. B. (2005): Influence of dietary zinc oxide and copper sulfate on the gastrointestinal ecosystem in newly weaned piglets. Applied and Environmental Microbiology, 71(5), 2267-2277.

20. Holman, D. B., Brunelle, B. W., Trachsel, J., \& Allen, H. K. (2017): Meta-analysis To Define a Core Microbiota in the Swine Gut. MSystems, 2(3), eoooo4-17.

21. Katouli, M., Lund, A., Wallgren, P., Kuhn, I., Soderlind, O., Mollby, R. (1997): Metabolic fingerprinting and fermentative capacity of the intestinal flora of pigs during pre- and post- weaning periods. Journal of Applied Microbiology, 83, 147-154.

22. Kelly, D., King, T.P. (2001): The Weaner Pig: Nutrition and Managment. In Varley, M. A., \& Wiseman, J.D., Kelly T. P. King (Eds.), Digestive Physiology and Development in Pigs (pp. 179-191). Bucksburn, Aberdeen, UK: CABI.

23. Kenny, M., Smidt, H., Mengheri, E., Miller, B. (2011): Probiotics - do they have a role in the pig industry? Animals, 3(5), 462-470.

24. Kirchgessner, M. ., Roth, F. X. (1982): Propionic acid as a feed additive in the rearing of piglets and fattening of pigs. Wirtschaftseigene Futter, 28, 225-234.

25. Lallès, J. P., Bosi, P., Smidt, H., Stokes, C. R. (2007): Weaning-a challenge to gut physiologists. Livestock Science, 108(1), 82-93.

26. Lallès, J. P., Boudry, G., Favier, C., Le Floc'H, N., Luron, I., Montagne, L., ... Sève, B. (2004): Gut function and dysfunction in young pigs: physiology. Animal Research, 2004(53), 301-306.

27. Lamendella, R., Santo Domingo, J. W., Ghosh, S., Martinson, J., Oerther, D. B. (2011): Comparative fecal metagenomics unveils unique functional capacity of the swine gut. BMC Microbiology, 11(1), 1-17.

28. Lee, Y. K., Mazmanian, S. K. (2010): Has the microbiota played a critical role in the evolution of the adaptive immune system? Science, 330(6012), 1768-1773. 
29. Leser, D. T., Amenuvor, J. Z., Jensen, T. ., Lindecrona, R. H., Boye, M., Møller, K. (2002): CultureIndependent Analysis of Gut Bacteria: the Pig Gastrointestinal Tract Microbiota Revisited. Applied and Environmental Microbiology, 68(2), 673-690.

30. Li, B. T., Van Kessel, A. G., Caine, W. R., Huang, S. X., Kirkwood, R. N. (2001): Small intestinal morphology and bacterial populations in ileal digesta and feces of newly weaned pigs receiving a high dietary level of zinc oxide. Canadian Journal of Animal Science, 81(4), 511-516.

31. Liao, S. F., \& Nyachoti, M. (2017): Using probiotics to improve swine gut health and nutrient utilization. Animal Nutrition, 3(4), 331-343.

32. Liu, P., Piao, X. S., Kim, S. W., Wang, L., Shen, Y. B., Lee, H. S., Li, S. Y. (2008): Effects of chito-oligosaccharide supplementation on the growth performance, nutrient digestibility, intestinal morphology, and fecal shedding of Escherichia coli and Lactobacillus in weaning pigs. Journal of Animal Science, 86(10), 2609-2618.

33. Liu, Y., Espinosa, C. D., Abelilla, J. J., Casas, G. A., Lagos, L. V., Lee, S. A., ... Stein, H. H. (2018): Nonantibiotic feed additives in diets for pigs : A review. Animal Nutrition, 4(2), 1-13.

34. Lodemann, U. (2010): Effects of Probiotics on Intestinal Transport and Epithelial Barrier Function. In R. R. Watson \& V. R. Preedy (Eds.), Bioactive Foods in Promoting Health: Probiotics and Prebiotics (p. 303). Boston, USA: Academic Press.

35. Looft, T., Allen, H. K., Cantarel, B. L., Levine, U. Y., Bayles, D. O., Alt, D. P., ... Stanton, T. B. (2014): Bacteria, phages and pigs: The effects of in-feed antibiotics on the microbiome at different gut locations. ISME Journal, 8(8), 1566-1576.

36. McCormack, U. M., Curião, T., Buzoianu, S. G., Prieto, M. L., Ryan, T., Varley, P., ... Lawlor, P. G. (2017): Exploring a possible link between the intestinal microbiota and feed efficiency in pigs. Applied and Environmental Microbiology, 83(15), 1-16.

37. Mikkelsen, L. L., Jensen, B. . (2004): Effect of fructo-oligosaccharides and transga- lacto-oligosaccharides on microbial populations and microbial activity in the gas- trointestinal tract of piglets post-weaning. Animal Feed Science and Technology, 117(1), 107-119.

38. Moeser, A. J., Pohl, C. S., Rajput, M. (2017): Weaning stress and gastrointestinal barrier development: implications for lifelong gut health in pigs. Animal Nutrition, 3(4), 313-321.

39. Morita, H., He, F., Fuse, T., Ouwehand, A. C., Hashimoto, H., Hosoda, M., ... Kurisaki, J. (2002): Adhesion of lactic acid bacteria to Caco-2 cells and their effect on cytokine secretion. Microbiology and Immunology, 46(4), 293-297.

40. Pajarillo, E. A. B., Chae, J. P., Balolong, M. P., Kim, H. B., Seo, K. S., Kang, D. K. (2015): Characterization of the Fecal Microbial Communities of Duroc Pigs Using 16S rRNA Gene Pyrosequencing. Asian-Australasian Journal of Animal Sciences, 4(28), 584-591.

41. Pedersen, R., Andersen, A. D., Mølbak, L., Stagsted, J., Boye, M. (2013): Changes in the gut microbiota of cloned and non-cloned control pigs during development of obesity: gut microbiota during development of obesity in cloned pigs. BMC Microbiology, 13(30), 1-9.

42. Pospišková, P., Zorníková, G., Kolářová, M., Sládek, Z., Komprda, T., Geršiová, J. (2013): Effect of probiotics in the pig nutrition on the pathogenic bacteria counts in the gut. Acta Universitatis Agriculturae et Silviculturae Mendelianae Brunensis, 6(61), 1839-1843.

43. Ramotar, K., Conly, J. M., Chubb, H., Louie, T. J. (1984): Production of menaquinones by intestinal anaerobes. Journal of Infectious Diseases, 150(2), 213-218.

44. Ross, G. R., Van Nieuwenhove, C. P., González, S. N. (2012): Fatty Acid Profile of Pig Meat after Probiotic Administration. Journal of Agricultural and Food Chemistry, 6o(23), 5974-5978. 
45. Stewart, C. S. (1997): Microorganism in hindgut fermentors. In R. Mackie \& B. White (Eds.), Gastrointestinal Microbiology (2nd ed.). New York: Chapman \& Hall Microbiol. Series.

46. Suo, C., Yin, Y., Wang, X., Lou, X., Song, D., Wang, X., Gu, Q. (2012): Effects of lactobacillus plantarum ZJ316 on pig growth and pork quality. BMC Veterinary Research, 8(1), 1-12.

47. Swords, W. E., Wu, C. C., Champlin, F. R., Buddington, R. K. (1993): Postnatal changes in selected bacterial groups of the pig colonic microflora. Biology of the Neonate, 63(3), 191-200.

48. Tang, Z. R., Yin, L. Y., Nyachoti, C. M., Huang, R. ., Li, T. J., Yang, C. B., ... Fan, M. Z. (2005): Effect of dietary supplementation of chitosan and galacto-mannan-oligosaccharide on serum parameters and the insulin like growth factor-I mRNA expression in early-weaned piglets. Domestic Animal Endocrinology, 28(4), 430-441.

49. Vahjen, W., Pieper, R., Zentek, J. (2010): Bar-coded pyrosequencing of $16 \mathrm{~S}$ rRNA gene amplicons reveals changes in ileal porcine bacterial communities due to high dietary zinc intake. Applied and Environmental Microbiology, 76(19), 6689-6691.

50. Van Kessel, A., Shirkey, T. W., Siggers, R. H., Drew, M. D., Laarveld, B. (2004): Commensal bacteria and intestinal development. Studies using gnobiotic pigs. In L. A. Tucker \& J. A. Taylor-Pickard (Eds.), Interfacing immunity, gut health and performance. Nottinghman, UK: Nottingham University Press.

51. Vo, N., Tsai, T. C., Maxwell, C., Carbonero, F. (2017): Early exposure to agricultural soil accelerates the maturation of the early-life pig gut microbiota. Anaerobe, 45, 31-39.

52. Vogel, R. F., Hammes, W.P., Habermeyer, M., Engel, K. H., Knorr, D., Eisenbrand, G. (2011): Microbial food cultures - opinion of the Senate Commission on Food Safety (SKLM) of the German Research Foundation (DFG). Molecular Nutrition \& Food Research, 55(4), 654-662.

53. Wang, A., Yu, H., Gao, X., Li, X., Qiao, S. (2009): Influence of Lactobacillus fermentum 15007 on the intestinal and systemic immune responses of healthy and $\mathrm{E}$. coli challenged piglets. Antonie van Leeuwenhoek, 96(1), 89-98.

54. Willing, B. P., Van Kessel, A. G. (2007): Enterocyte proliferation and apoptosis in the caudal small intestine is influenced by the composition of colonizing commensal bacteria in the neonatal gnotobiotic pig. Journal of Animal Science, 85(12), 3256-3266.

55. Yang, H., Huang, X., Fang, S., He, M., Zhao, Y., Wu, Z., ... Huang, L. (2017): Unraveling the fecal microbiota and metagenomic functional capacity associated with feed efficiency in pigs. Frontiers in Microbiology, 8(1555), 1-11.

56. Yolton, D., Savage, D. C. (1976): Influence of certain indigenous gastrointestinal microorganisms on duodenal alkaline phosphatase of mice. Applied and Environmental Microbiology, 31(6), 880-888.

57. Zimmermann, J. A., Fusari, M. L., Rossler, E., Blajman, J. E., Scharpen, A. R., Astesana, D. M., ... Signorini, M. V. (2016): Effects of probiotics in swines growth performance: A meta-analysis of randomised controlled trials. Animal Feed Science and Technology, 219, 280-293. 


\section{THE ROLE OF GUT MICROBIOTA ON MAINTAINING HEALTH OF PIGS}

\section{Summary}

Stable gut microbiota may influence the health and wellbeing of pigs. Results of up-to-date studies have shown a positive effect of gut microbiota on feed efficiency, improvement of morphological and physiological characteristics of gastrointestinal (GI) tract, prevention of breach of pathogenic species, as well as a positive role in immunology. However, besides beneficial bacterial species, gut microbiota of pigs can include pathogens such as Salmonella spp., Clostridia spp. and pathogenic strains of E. coli. When the balance of naturally present microbial communities is disturbed, these pathogens can cause illness of pigs, causing production losses. Antibiotics were used in the past for ensuring a stable gut microbiota, but since damaging effects of such practice were recognized, alternative methods have been considered, such as the use of probiotics and prebiotics. For this approach, it is necessary to know the composition and abundance of microbial communities in GI tract of healthy pigs, as well as to identify the most important microorganisms that have a role in the prevention of infection and maintaining the wellbeing of the host. Therefore, many studies have been focused on defining and detailed characterization of gut microbiota of healthy individuals, to study interactions between microbes as well as microbial interactions with the host. Also, different approaches have been considered to ensure a stable gut microbiota to maintain vitality and health of animals.

Key-words: pigs, gastrointestinal (GI) tract, microbiota, probiotics, prebiotics

Primljeno: 03.12.2019.

Prihvaćeno: 19.12.2019. 